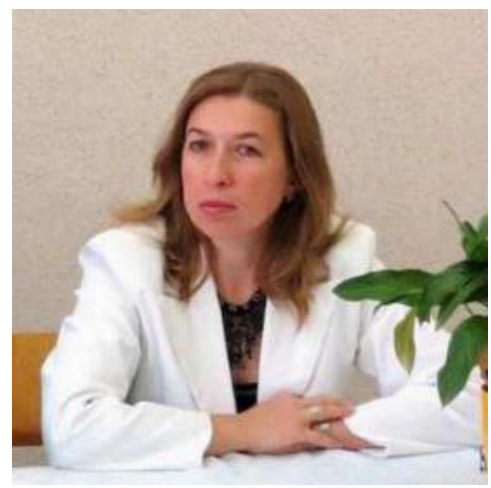

\title{
Оксана Кондур,
}

кандидат фізико-математичних наук, доцент, ДВНЗ «Прикарпатський національний університет імені Василя Стефаника» (м. Івано-Франківськ)

\section{Oksana Kondur,}

Candidate of of Physics and Mathematics Sciences, Associate Professor, Vasyl Stefanyk Precarpathian National University (Ivano-Frankivsk) oxikon13@gmail.com

\section{ТРАНСФОРМАЦІЇ ОСВІТНЬО-НАУКОВИХ УПРАВЛІНСЬКИХ МОДЕЛЕЙ У КОНТЕКСТІ ІНФОРМАЦІЙНОЇ РЕВОЛЮЦІЇ ГЛОБАЛЬНОЇ СИСТЕМИ ОСВІТИ}

\section{TRANSFORMATION OF EDUCATIONAL AND SCIENTIFIC MANAGEMENT MODELS IN THE CONTEXT OF THE INFORMATION REVOLUTION OF THE GLOBAL EDUCATION SYSTEM}

У статті проведено аналіз управлінських та інформаційних процесів сучасної системи освіти в умовах глобалізації. Описано інституційний аспект глобалізації освіти.

Обґрунтовано, що збільшується попит на освіту, яка розповсюджується за допомогою інформаційних технологій. При цьому електронний освітній простір повинен містити в собі систему керівництва та контролю над процесом передачі та засвоєння знань.

Відзначається, що перебудова економіко-політичних систем в усьому світі відбулась паралельно із впровадженням інформаційних технологій у різні сфери життя. Глобальні суспільні та економічні трансформації потребують також реструктурування освіти. Зміни в попиті на послуги освіти покликані зробити більш гнучкою пропозицію в освітній сфері.

Ключові слова: глобалізація, освіта, система вищої школи, віртуальний університет, суспільні трансформації, інформаційні системи.

The article is devoted to the research of administrative and information processes of the modern education system in the conditions of globalization. The institutional aspect of the globalization of education is described.

It is substantiated that the demand for education, which is spreading through information technologies, is increasing. In this case, the e-learning space should include a system of guidance and control over the transfer and learning process.

It is noted that the restructuring of economic and political systems around the world took place in parallel with the introduction of information technology in various spheres of life. Global social and economic transformations also require restructuring of education. Changes in the demand for education services are intended to make the proposal more flexible in the educational field.

Keywords: globalization, education, system of high school, virtual university, social transformation, informational systems.

В работе проведен анализ управленческих и информационных процессов современной системы образования в условиях глобализации. Описано инстуциональный аспект глобализации образования.

Обосновано, что увеличивается спрос на образование, распространяется с помощью информационных технологий. При этом электронное образовательное пространство должно включать в себя систему управления и контроля над процессом передачи и усвоения знаний.

Отмечается, что перестройка экономико-политических систем во всем мире состоялась параллельно с внедрением информационных технологий в различные сферы жизни. Глобальные общественные и экономические трансформации требуют также реструктурирования образования. Изменения в спросе на услуги образования призваны сделать более гибким предложение в образовательной сфере.

Ключевые слова: глобализация, образование, система высшей школы, виртуальный университет, общественные трансформации, информационные системы.

Постановка проблеми в загальному вигляді та її зв'язок з важливими науковими та практичними завданнями. Характерною рисою сучасного світу $є$ глобалізація процесів як на рівні держав, так і окремих індивідів. Це зумовлює пошук нових світоглядних орієнтирів та їх формування через освітню систему. При цьому основна функція освіти в сучасних умовах - це не тільки розвиток особистості, а й забезпечення стійкого соціально-економічного та науково-технологічного розвитку країни з урахуванням як особливих національних і соціокультурних цінностей, так і глобальних тенденцій [7]. Водночас сучасні світові вимоги розвитку освіти та економіки, як середовища її існування, трансформували заклади освіти у сукупність бізнес-процесів, які 
об'єднані в інформаційну та управлінську систему. Ці освітньо-управлінські тенденції необхідно використати для радикальної перебудови освіти на демократичних засадах.

Негативним наслідком глобалізації стало посилення соціально-економічною нерівності в суспільстві, що вплинуло на зростання нерівності в отриманні та використанні інформації й відповідно знань, нерівності у культурному та соціальному капіталі. Перетворення у освітній сфері повинні усунути ці проблеми і зробити освіту суспільним інститутом в інтересах соціальної більшості

Чимало наукових досліджень присвячена глобалізації управління освітою. Водночас процеси регіоналізації і децентралізації, посилення місця вибору в освітньому процесі вимагають нових управлінських рішень та їх наукового обґрунтування.

На початку нашого століття школа (від початкової до вищої) як соціально-культурний інститут і сам освітній процес набувають кардинально нових характеристик. Тому вивчення управлінських процесів в освітній галузі неможливе без розуміння сутнісних змін в об'єктах управління, а саме: в організації навчального процесу, у змісті освіти, в інституційних характеристиках навчальних закладів. Демократизація управління, з одного боку, виявилася неузгодженою з освітніми завданнями, а, з іншого боку, спроби гуманізації освітнього процесу в основному не підтримувалися відповідними управлінсько-організаційними змінами.

Аналіз останніх досліджень і публікацій, у яких започатковано розв'язання проблеми. Такими вченими як А. Бадью, Б. Бернштейн, Ю. Габермас, А. Жіро, С. Жижек, Д. Келлнер, Г. Маркузе, К. Поппер, Г. Райхельт, Ч. Рейч, П. Фрейре, М. Фуко критично оцінено уявлення про соціальний і культурний зміст освіти. Філософсько-педагогічні концепції демократичної освіти знайшли своє відображення у працях таких вчених, як Ж.-Ж. Руссо, С.І. Гессен, Дж. Дьюї, А. Нейл, Гутман, Ш. Амонашвілі, У. Паркер, Д. Спрінг, А.Н. Тубельський та ін. Проблемами освітніх інновацій і реформ займались М. Кирст, С. Сарасон, М. Фуллан, Д. Чапмен та ін. Соціологічні, педагогічні і психологічні дослідження освіти як цілісного інституту проводили Т. Парсонс, Е. Етционі, А.С. Макаренко, В.О. Сухомлинський, Р. Мейган, П. Мортімор, Д. Рейнолдс [4].

Демократизації управління освітою присвятили свої дослідження такі вітчизняні науковці, як Л. Антошкіна, Л. Березівська, Л. Ващенко, Л. Гаєвська, В. Зінченко, Г. Єльнікова, В. Кремень, С. Крисюк, В. Луговий, І. Лікарчук, В. Майборода, Н. Нижник та ін.

Формування мети статті. Глобалізаційні світові процеси сприяли інтенсивному розвитку інформаційних технологій. У результаті відбувся перехід від постіндустріального до інформаційного суспільства, у якому основним капіталом є знання та інформація. Такі перетворення висунули нові вимоги до змісту і цілей освітньої системи, а отже потребує трансформації менеджмент цієї сфери. Проаналізуємо управлінські та інформаційні процеси сучасної системи освіти в умовах глобалізації.

Виклад основного матеріалу дослідження з повним обґрунтуванням отриманих наукових результатів. у будь-якій освітній системі найосновніше - це вчитися. Проте освіта не зводиться тільки до отримання знань. Протягом тисячоліть в умовах повільного прогресу за життєвий цикл одного покоління вимоги до обсягу знань та рівню вмінь, моральні стандарти і релігійні належності фактично не зазнали змін. Але за останні десятиліття зміст і характер необхідних знань і вмінь за час активності одного життєвого циклу кардинально оновлюється кілька разів. Все це зумовлене переходом до інформаційної моделі суспільства. За таких умов виникає гостра потреба створення великомасштабних систем для отримання додаткових знань чи перекваліфікації великої кількості потенційно цінних працівників. Водночас зросла потреба у числі носіїв знань та вмінь високої кваліфікації [5]. Реалізація всіх цих вимог без створення відповідних освітніх систем неможлива.

Інституційний аспект глобалізації освіти полягає у наступному:

- забезпечення варіанту рівності освітніх можливостей, орієнтованого на компенсацію соціальної і культурної нерівності під час участі в освітньому процесі через подолання механізмів соціальноекономічної й культурної селекції;

- виявлення і подолання чинників обмежень в організації і змісті освіти на основі досвіду вільної освіти;

- демократизація освітнього процесу на основі відповідального вибору форм і змісту навчання;

- підтримка різноманіття форм і змісту освіти для задоволення потреб громадян;

- узгодження інтересів різних груп, залучених в ухвалення рішень у сфері освіти, через відкриті канали комунікації і критичну дискусію;

- розширення автономії навчальних закладів у вертикальній системі управління в контексті посилення суспільного характеру управління освітою.

«Вибір моделі управління освітою пов'язаний зі специфікою соціально-політичних умов країни», про що свідчить аналіз зарубіжного досвіду державного управління розвитком системи освіти в провідних країнах світу [1]. Соціально-економічні трансформації в українському суспільстві спричинили інноваційні процеси у функціонуванні навчальних закладів,що посилило потребу зміни традиційних поглядів на управління. Стійкого розвитку як країни в цілому, так і окремих галузей суспільного життя можна досягти лише шляхом реформ, орієнтованих на інновації, зокрема впровадження демократичних засад в управлінську діяльність у тісному зв'язку з децентралізацією надання послуг[6]. 
Як зазначають науковці, «демократизація управління освітою реалізується перш за все в залученні до цього процесу різних соціальних груп населення (викладачів, студентів, представників бізнесу та ін.). Результатом модернізації управління вищою освітою має стати розробка й упровадження відкритої моделі, побудованої на принципах поєднання централізації та децентралізації, активного залучення всіх зацікавлених сторін до управління освітою, поєднання внутрішньої самооцінки вищих навчальних закладів і зовнішньої оцінки їх діяльності незалежними організаціями та експертами.» [3].

Відбулась трансформація парадигми освіти від «освіти на все життя» до «освіти протягом життя». При цьому зміни в попиті на послуги освіти не тільки стосуються окремих моментів доступу до освіти протягом життя людини, але і покликані зробити гнучкішою пропозицію в сфері освіти. Зокрема активно впроваджуються методи логістики, наприклад - модель «оперативної поставки», за якою споживач може отримувати освітні програми (часто короткострокові) в тому вигляді і в той час, коли в цьому виникне необхідність.

Наслідками того, що пропозиція на ринку освіти має відповідати моделі «оперативної поставки», є: 1) освіта скоріше «тягнеться» за ринковим попитом, ніж «проштовхується» самостійно; 2) збільшення гнучкості пропозиції на ринку освітніх послуг вимагає шукати нові засоби для постачання цих послуг; 3) виникає потреба у частішому застосуванні високотехнологічних засобів, щоб користувачі (навчальні заклади та здобувачі освіти) з їх допомогою могли впоратися з гнучкістю пропозиції і попиту без зайвих витрат. Тобто збільшується попит на освіту, яка розповсюджується за допомогою інформаційних технологій.

Завдяки розширенню мобільних технологій теоретично можна забезпечити навчання для всіх і в будь-який зручний час. Одним із найвідоміших у світі новим способом отримання знань для широких мас $є$ дистанційне навчання. Великий крок вперед матеріальне, технічне оснащення дистанційного навчання зробило з появою Інтернету, який є глобальною, самоорганізуючою, незалежною, загальнодоступною інформаційною мережею. Інтернет - це вдала форма реалізації ідеї В.Вернадського, Е. Ле-Руа і Тейяра де Шардена [2] про ноосферу як саморозвиваючу, розумову, моральну «оболонку» земної кулі.

Але така освіта може бути лише вищою чи їй еквівалентною й аж ніяк не середньою. Адже через досвід шкільного і/або студентського життя найперше відбувається соціалізація особистості.

Нині різноманітні центри та інститути дистанційного навчання, віртуальні університети, територіальні організації, міжвузівські об'єднання активно пропонують програми навчання за освітнім рівнем бакалавр і магістр, як правило, у заочно-дистанційній формі.

При дистанційному навчанні є проблема відсутності зворотного зв'язку. І, на жаль, чомусь не актуалізуються проблеми якості освіти, контролю надійності засвоєння знань, та взагалі питання, які науки і кому не можна викладати дистанційно. Зрозуміло, що фахівці із отриманим дистанційно дипломом лікаря, інженера, математика, хіміка, фізика, біолога, є ненадійними, а деколи і небезпечними.

Електронний освітній простір повинен містити в собі як важливу складову інтерактивну систему керівництва та контролю над дистанційним спілкуванням студента з викладачем. Тільки так можна забезпечити якість навчання, наближену до стаціонарної форми. При цьому важливе виконання наступних умов.

По-перше, наявність у студентів мотивації, тобто студенту цікаво вчитися (отримувати певні знання) або ж він зацікавлений у затребуваності на ринку праці. Ідеально, коли ці дві мотивуючі складові збігаються. Але основне, що студент хоче отримати знання, а не тільки диплом як документ. Хоча останнє теж можливе, особливо, коли мова йде про формальну перекваліфікацію.

По-друге, реальне існування інформаційного середовища, в якому існує навіть простий обиватель. Цей процес зреалізований вже кілька десятиліть в економічно розвинених країнах і лиш активізувався останніми роками у нас, бо навіть доступ до всесвітніх інформаційних мереж не є тотальним.

Ідея віртуального кампусу насправді полягає в тому, щоб якнайповніше і у найкоротші терміни та за якнайменші гроші задовольнити вимоги ринку праці, вимоги гідного працевлаштування.

Перебудова економіко-політичних систем в усьому світі за останні роки відбулась паралельно із впровадженням інформаційних технологій у виробництво та фінансування з метою скорочення витрат виробництва шляхом автоматизації. Глобальні суспільні та економічні трансформації потребують реструктурування освіти, яке б забезпечило два основних аспекти. Перший пов'язаний з вирішенням проблем гнучкості ринку праці, а саме: освіта повинна підвищити продуктивність праці в конкретній державі або регіональному блоці. Другий аспект зумовлений тим, що освіта при такому реструктурування є одним із секторів промисловості, які підлягають комерціалізації, тобто теж має отримувати прибуток.

Отже, глобальне реструктурування світової системи, яке ґрунтується на знаннях, робить освіту головною у підвищенні продуктивності праці. Так, у «Лісабонської стратегії» викладена основна мета урядів об'єднаної Європи: Європейський союз повинен стати «співтовариством 3 найбільш конкурентоспроможною та найдинамічнішою в світі, заснованою на знаннях економікою» [8; 13]. Тобто освіта вже давно стала сектором економіки, здатним приносити надприбутки [9; 15]. Тому міжнародний капітал щорічно організовує в Канаді міжнародні форуми фірм та інвесторів, які бажають розробляти ринок науково-освітніх послуг [16].

Для завоювання світового ринок вищої освіти формуються партнерські відносини між дослідницькими інститутами та постачальниками знань із приватного сектору. Наприклад, в Америці створені об'єднання 
університетів Берклі, Мічиганський, Колумбійський із корпораціями Time Warner, Disney Corporation, Microsoft та ін.; в Англії університет Великобританії об'єднався з американською компанією UNEX, яка організувала інтернет-університет Cardean; в Африці Світовий банк і ЮНЕСКО фінансують Африканський віртуальний університет, який складається із 22 африканських інституцій із залученням викладачів провідних закладів вищої освіти Північної Америки, Африки і Європи. [10; 11; 12].

Останнім часом зросла популярність інтернет-університетів, які розповсюджують освітні продукти - «знання», «компетентності»-дистанційно, що забезпечує «оперативну доставку» і найперше становить інтерес для ділових структур. При цьому технологічно у найпростішому випадку використовують електронну пошту для розсилки лекцій та конспектів, інтернет-технологію чатів для організації онлайн-семінарів; складніші моделі застосовують інтерактивні інтерфейси в мережі [8]. Дистанційне навчання онлайн пропонують: у США - університет Фенікса [14]; в Африці - Африканський віртуальний університет [10]; в Австралії - Western Governers University i Motorola University [12]; в Кореї [11]. Проте зауважимо, що здатність засвоювати знання так, щоб вони могли дати фахову реалізацію, залежить від віку. Правильна, необхідна, освіта має бути отримана у правильний час. Знання треба набувати за чітким порядком й у відповідності з їх внутрішньою логікою.

За концепцією «освіти протягом життя» зростатиме попит на по життєвй доступ до освіти для перепідготовки. Особливо з боку комерційних структур, які фінансовими важелями змушуватимуть університети складати освітні програми так, щоб вони відповідали потребам ринку. Це зумовить заклади вищої освіти замість надання освітніх послуг за кількарічний термін переходити на більш комерційно орієнтовані короткотермінові курси для своїх «споживачів». Фактично заклади змагатимуться за контракти з роботодавцями, особливо - з великими корпораціями.

Висновки і перспективи подальших досліджень. Мінливий характер ринку праці означає, що заклади вищої освіти повинні оперативно і гарантовано надавати добрі послуги з професійної підготовки. Не кожний із закладів витримає конкуренцію, що призведе до формування їх ієрархії та до появи відокремленого транснаціонального класу менеджерів глобальної економіки. Попит на освітні послуги набуває короткострокового характеру, що зумовить велику гнучкість і посилить ієрархізацію робочої сили в академічній сфері. Зростатиме глобальна конкуренції на ринку праці.

Розвиток гнучкого дистанційного навчання з використанням електронних технологій призведе до збільшення числа громадян, які отримують вищу освіту (особливо для підвищення професійного рівня), що позитивно вплине на рівень свідомості та культури суспільства. Дистанційне навчання може бути масовим для достатньо зрілих, дорослих людей, свідомо бажаючих вчитися. Причому навчання має бути регулярне, відповідно сертифіковане і таке, що дає визнаний на ринку праці диплом і відповідний йому набір знань та вмінь.

Освіта повинна бути реконструйованою до вирішення завдань науково-технічної революції та адаптації до змінних ринкових умов, а глобалізацію й технологічну революцію треба використати для радикальної перебудови освіти у напрямку її демократизації і прогресивних соціальних змін

Більшість великих і середніх установ, підприємств, організацій впроваджують передові західні стандарти інформаційного управління. Економічної ефективності освіти також можна досягти за рахунок використання управлінських інформаційних систем, зокрема корпоративних інформаційних систем. Тому варто дослідити модифікацію методів корпоративного управління для освітньої галузі.

1. Бабічев А. В. Зарубіжний досвід із питань управління змінами в системі вищої освіти / А.В. Бабічев // Теорія та практика державного управління. - 2( 57) /2017. - С.1-9.

2. Вернадский. В. И. Биосфера и ноосфера // Книга «Научная мысль как планетарное явление». - Москва, 1977. - С.139-150.

3. Громадська участь у творенні та здійсненні державної політики / Уклад.: Е. А. Афонін, Л. В. Гонюкова, Р. В. Войтович. Київ, 2005. - 250 с

4. Зінченко. В. Неоліберальна модель глобального розвитку, критична соціальна філософія освіти і світові системні перспективи демократичної інституалізації / В. Зінченко // Філософія освіти. - 2014, №1(14). - С.127-157.

5. Карлов Н.В. Ноосфера образования. область удаленного доступа к знаниям / Н.В. Карлов, Н.Н. Кудрявцев. - [Електронний ресурс]. Режим доступу: http://spkurdyumov.ru/education/noosfera-obrazovaniya/

6. Кремень В. Освіта і наука У країни. Шляхи модернізації / В. Кремень. - К. : Грамота, 2003. - 216 с.

7. Ярошенко А.О. Потенціал і ефективність освітньо-інформаційної політики. - К.: НПУ імені М.П.Драгоманова, $2009 .-256$ с.

8. 11. Cole M. Globalisation, Modernisation and Competitiveness: a critique of New Labour in Education / M. Cole //International Studies in Sociology of Education. - 2008. - v. 8 n. 3. - P.315-332. - 182 p.

9. CVCP and HEFCE. The Business of Higher Education: UK Perspectives, 2010. - www.cvcp.ac.uk.and www.hefece.ac.uk.

10. Mactar D. «The African Virtual University: Bridging the Gap for Development», TechKnowLogia, 2009, 1:1 Jan/Feb. - Available at: www.techknowlogia.org.

11. Insung J.«Korea: Virtual University Trial Project», TechKnowLogia,2010, 1:1, Jan/Feb. - Available at: www.techknowlogia.org.

12. NTEU (National Tertiary Education Union - Australia), Universitas21 and NewsCorp - going global or going under?, Media Release, 20 Nov. - Available at: http://www.nteu.org.au/whatsnew/newmediarel/universitas2115 nov.pdf

13. Osterwalder K. Conclusions of the Thematic Groups: Report on the conclusions of Convention of European Higher Education Institutions, Salamanca, 2001, 29-30 March.- Available at: http://www.salamanca2001.org.

14. University of Phoenix. - Available at: www.uophx.edu

15. Warwick D. The Future Business of Universities, Speech to the Association of Business Schools. - Available at: www.universitiesuk. ac.UK/services. 
16. World Education Market, May 21-24, 2015, Vancouver Exhibition and Conference Centre, Vancouver, British Columbia, Canada. - Available at: http://www.wemex.com.

\section{Reference}

1. Babiczev A.V. Zarubizhnyj dosvid iz pytan upravlinnia zminamy v systemi vyshchoji osvity // Teorija ta praktyka derzhavnogo upravlinnia.- 2( 57) /2017. - S.1-9.

2. Vernadskyj V.I. Biosfera i noosfera // Knyga «Nauchnaja mysl kak planetarnoe javlenie»- Moskva, 1977. - S.139-150.

3. Gromadska uchast u tvorenni ta zdijsnenni derzhavnoji polityky / Uklad. E.A. Afonin, L.V. Goniukova, R.V.Vojtovych. - Kyjiv, 2005. $250 \mathrm{~s}$.

4. Zinchenko V. Neoliberalna model globalnogo rozvytku, krytychna socialna filosofija osvity. // Filosofija osvity. - 2014, №1(14). S. $127-157$.

5. Karlov N., Kudriavcev N. Noosfera obrazovanija oblast udalennogo dostupa k znanijam. - Available at: http://spkurdyumov.ru/ education/noosfera-obrazovaniya/

6. Kremen V. Osvita I nauka Ukrajiny. Shliahy modernizaciji. - Kyjiv. : Gramota, 2003. - 216 p.

7. Jarochenko A.O. Potencial I efektyvnist osvitnio-informacijnoji polityky. - K.: NPU imeni M.Dragomanova, 2009. - 256 p.

8. 11. Cole M. Globalisation, Modernisation and Competitiveness: a critique of New Labour in Education / M. Cole //International Studies in Sociology of Education. - 2008. - v. 8 n. 3. - P.315-332. - 182 p.

9. CVCP and HEFCE. The Business of Higher Education: UK Perspectives, 2010. - Available at: www.cvcp.ac.uk and www.hefece. ac.uk.

10. Mactar D. «The African Virtual University: Bridging the Gap for Development», TechKnowLogia, 2009, 1:1, Jan/Feb. - Available at: www.techknowlogia.org.

11. Insung J. Korea: Virtual University Trial Project. TechKnowLogia, 2010, 1:1, Jan/Feb. - Available at: www.techknowlogia.org.

12. NTEU (National Tertiary Education Union - Australia), Universitas21 and NewsCorp - going global or going under?, Media Release, 20 November. - Available at: http://www.nteu.org.au/whatsnew/newmediarel/universitas2115 nov.pdf

13. Osterwalder K. Conclusions of the Thematic Groups: Report on the conclusions of Convention of European Higher Education Institutions, Salamanca, 2001, 29-30 March.- Available at: http://www.salamanca2001.org.

14. University of Phoenix. - Available at: www.uophx.edu.

15. Warwick D. The Future Business of Universities, Speech to the Association of Business Schools. - Available at: www.universitiesuk. ac.UK/services.

16. World Education Market, May 21-24, 2015, Vancouver Exhibition and Conference Centre, Vancouver, British Columbia, Canada. Available at: http://www.wemex.com.

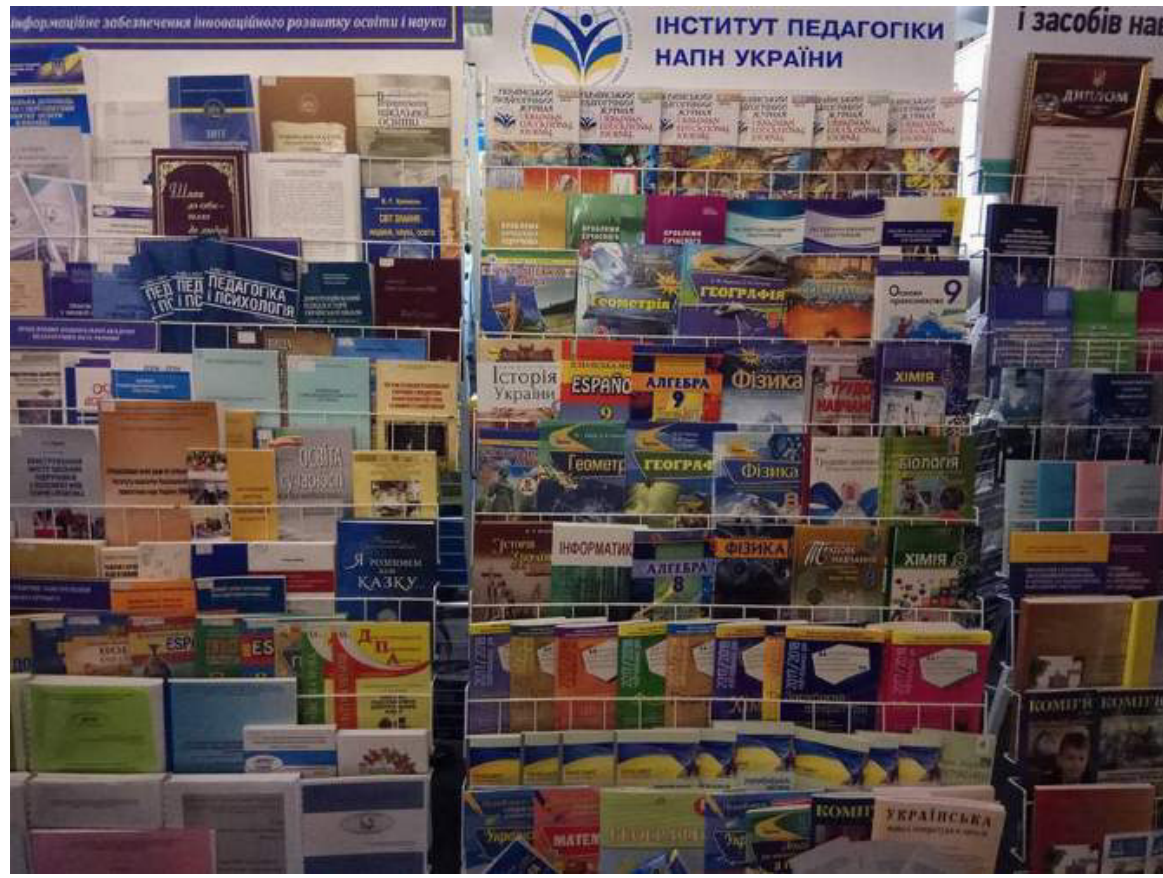

